\title{
Peripheral Blood Lymphocyte Culture of Rhinella arenarum
}

\author{
R. Agüero, S. M. Marsa, L. E. Moreno, M. E. Vasquez Gomez* \\ Department of Biochemistry and Biological Sciences, Faculty of Chemistry, Biochemistry and Pharmacy, National University of \\ San Luis, San Luis, Argentina \\ Email: *eridnere@gmail.com
}

How to cite this paper: Agüero, R., Marsa, S.M., Moreno, L.E. and Vasquez Gomez, M.E. (2017) Peripheral Blood Lymphocyte Culture of Rhinella arenarum. Open Access Library Journal, 4: e4212.

https://doi.org/10.4236/oalib.1104212

Received: November 27, 2017

Accepted: December 22, 2017

Published: December 25, 2017

Copyright $\odot 2017$ by authors and Open Access Library Inc.

This work is licensed under the Creative Commons Attribution International License (CC BY 4.0).

http://creativecommons.org/licenses/by/4.0/

\begin{abstract}
The cytogenetic identification is important for the characterization of an organism. In amphibians, the direct method is a technique of routine for chromosomal characterization, but is necessary for the sacrifice of the copies. The aim of this work is to develop the technique of lymphocyte cultures for the species Rhinella arenarum without sacrifice of specimen. Materials and Methods: Male specimens' Rhinella arenarum were collected at San Luis; the blood sample was obtained by cardiac puncture. The mediums tested were: the culture media: RPMI 1690 with HEPES and Glutamine, MEM and F10; and different volumes of: phytohemagglutinin, penicillin-streptomycin, fetal bovine serum and colchicine. Results: For the standardization of the protocol we rely on cell culture techniques of fish and human. The following parameters were standardized: volume blood: volume of $100 \mu \mathrm{l}$; culture medium was chosen: the best results were observed with RPMI 1640; fetal bovine serum: he worked with a volume of $500 \mu \mathrm{l}$ in the case of RPMI 1640 and F10, for MEM $1000 \mu \mathrm{l}$ was used; phytohemagglutinin: it was observed that large volumes of this reagent agglutinated cells, and hence the greater number of metaphases was obtained with $10 \mu \mathrm{l}$; colchicine: best chromosome size was observed with $100 \mu \mathrm{l}$ and an incubation time of $12 \mathrm{~h}$. Conclusion: The standardized protocol is a simple and inexpensive technique that does not require equipment or facilities of high complexity and specimen are kept alive.
\end{abstract}

\section{Subject Areas}

Biochemistry

\section{Keywords}

Amphibian, Cytogenetics, Metaphase 


\section{Introduction}

In general, anuran amphibians, despite the large number of species and the diversity of habitats, show conserved morphological characteristics, which make phylogenetic research difficult [1]. In the Anura order, there is a general tendency to complement morphological data with alternative data including karyotype, allozyme patterns and mitochondrial gene sequences, which have provided new insights into the taxonomy and phylogeny of this group [2].

The morphological characteristics of the chromosomes, such as the number, shape, size, presence of secondary constrictions, which together make up the karyotype, give a vision for the chromosomal analysis of individuals or populations of a particular species, which makes it possible to return to evaluate the anuran system [3] [4]. Cytogenetic identification is an important parameter for the identification of an organism in its natural habitat. The first step of genomic analysis involves the karyotype of mitotic chromosomes to determine the genomic organization of the organism at the cytological level [5]. In amphibians, the direct method is the technique routinely used in chromosomal characterization works. It consists in the administration of a concentration of colchicine, depending on the author, in vitro or in vivo to the specimens and the sacrifice of the same for the extraction of the tissues of the intestine, bone marrow and testicles, from which the cells are in metaphases [6] [7] [8] [9]. Although this technique provides good results, it has the disadvantage of sacrificing the specimens to study, a fact of vital importance when animals are at risk of extinction or threatened, so this type of trials represents a risk to their population.

The culture of lymphocytes is a technique that has been protocolized for different groups or species, from the original standardized technique for humans [10]. This is because it is a minimally invasive technique that provides us with a good number and quality of metaphases [5] [11] [12] [13] [14] [15]. This aspect is important because with the implementation of this technique we could work on species that are in danger of extinction or threatened, because only a small volume of blood would be required for their characterization. In addition, this technique is simple and inexpensive, which makes it possible to use it routinely in a laboratory of animal cytogenetic.

The species Rhinella arenarum, also called "common toad", belonging to the class Amphibia, order Anura and family Bufonidae, presents a series of characteristics that position it as a viable model within the group of amphibians. One of them is that this amphibian lives in both humid and arid environments and its territorial range in Argentina extends from the north of the province of Jujuy to near the Patagonian coast so its collection can be done in all seasons of the year in anywhere in the country. In addition, this species, despite its ecological and phenotypic diversification, is a genetically cohesive group [16], so that the results obtained can be compared with those of the direct method. This species is not in danger of extinction or threatened [17], so the tests carried out on it do not represent a risk for its population. 
The objective of the present work is to culture amphibian lymphocytes based on the Rhinella arenarum species. Different tests will be carried out to try to optimize these crops through the use of different media and temperatures.

\section{Materials and Methods}

Sample: 10 male adults of Rhinella arenarum, were collected manually [18], in nocturnal samplings in the city of San Luis, Capital Department, Argentina $\left(33^{\circ} 20^{\prime} \mathrm{S}, 66^{\circ} 20^{\prime} \mathrm{W}\right)$. The sexual determination of the individuals was made based on the external phenotype. The presence of air sacs in the males was confirmed, as well as the presence of blackish nuptial callus on the first toe of the front legs and by observing the forearm, pronouncedly larger in males than in females [19]. The specimens were kept in captivity for 1 week until the extraction of the blood sample in the bioterium of the National University of San Luis. Once the extraction was done, they were monitored until they were fully recovered and returned to their natural habitat. We followed the general guidelines for the care and use of laboratory animals recommended by the Animal Care Committee of the National University of San Luis.

Cardiac puncture: The surfaces of the thorax and abdomen were carefully disinfected with alcohol $70 \%$ before the cardiac puncture. The blood sample of the amphibians was obtained by direct puncture of the ventricle, using tuberculin syringes and 25G needles, previously heparinized, after having obtained the sample, the lymphocyte culture stage was carried out.

Reagents used: The culture media tested were: RPMI 1690 with HEPES and Glutamine, MEM and F10. Different volumes of: phytohemagglutinin, streptomycin penicillin, fetal bovine serum and colchicine. In Table 1, the volumes and reagents used in the development of the technique are given.

Work temperature: We worked in a stove at $28^{\circ} \mathrm{C}$, because the amphibians are ectothermic and this is their physiological temperature

Incubation time: The cultures were incubated for 60 hours, with the addition of colchicine 12 hours before finishing the culture.

Harvest: This start with a centrifugation at $1200 \mathrm{rpm}$ for 10 minutes at $27^{\circ} \mathrm{C}$,

Table 1. Reagents and volumes used.

\begin{tabular}{cccc}
\hline Cultivation components & Characteristics & Provider & Testied volumes \\
\hline Blood sample & MEM & Wild specimens & $100,150,200 \mu \mathrm{l}$ \\
Culture medium & RPMI 1640 & Gibco & $5 \mathrm{ml}$ \\
& F1O & Gibco & Gibco \\
Phytohemagglutinin & PHA-M & Gibco & $10,20,30,50,100 \mu \mathrm{l}$ \\
Streptopenicillin & & Gibco & $0,100 \mu \mathrm{l}$ \\
Fetal bovine serum & Sterilized by irradiation & Natacor & $1000 \mu \mathrm{l}(\mathrm{MEM})$ \\
Colchicine & $10 \mu \mathrm{g} / \mathrm{ml}$ & Gibco & $500 \mu \mathrm{RPMI}, \mathrm{F} 10)$ \\
\hline
\end{tabular}


then the supernatant was removed and $10 \mathrm{ml}$ of hypotonic $\mathrm{KCl}$ solution at $0.56 \%$ was added, leaving them in incubation at $28^{\circ} \mathrm{C}$ for 30 minutes. It was then centrifuged at $1200 \mathrm{rpm}$ for 10 minutes and the supernatant discarded. Then $4 \mathrm{ml}$ of Carnoy solution 6:1 was added and incubated for 30 minutes. The samples were centrifuged at $1200 \mathrm{rpm}$ for 10 minutes. $5 \mathrm{ml}$ of Carnoy solution 3:1 was added and was incubated for 15 minutes. The supernatant was discarded and finally 1 $\mathrm{ml}$ of the Carnoy solution 3:1 was added and the pellet was resuspended. The slides were prepared by means of the splash technique. They were colored with a $5 \%$ Giemsa solution for 5 minutes. Then they were observed under a microscope with a magnification of $100 \times$. Below is a summary of the protocol used (Figure 1).

\section{Results}

For the standardization of the Rhinella arenarum peripheral blood lymphocyte culture protocol, we were based on the in vitro culture techniques of fish lymphocytes [15] and on the lymphocyte culture protocol in humans [10]. In order to standardize it, a series of parameters were set that are discussed below:

Volume of blood sample: The volume of the blood sample varied among the different specimens. In general, 100 - $200 \mu \mathrm{l}$ of sample were obtained, but exceptionally, up to $400 \mu \mathrm{l}$ was collected.

In lymphocyte culture techniques, a pre-culture stage consists of separating the lymphocyte-rich plasma from the red blood cells; however this was not possible due to the small volume of total blood obtained from each specimen. For this reason, to carry out the lymphocyte culture, different volumes of whole blood were tested: 100,150 and $200 \mu \mathrm{l}$. The volume of $100 \mu \mathrm{l}$ of blood was chosen, due to the fact that a good number of metaphases were observed per field. In higher volumes there were an excessive number of nuclei without the presence of metaphases.

Culture medium: The best results were observed with RPMI 1640 medium (Gibco) since the highest number of metaphases was obtained, however, with MEM (Gibco) and F10 (Gibco) media, although cell growth was obtained, the number of metaphases was lower.

Bovine fetal serum: Based on the techniques of in vitro culture of lymphocytes in humans, we worked with a volume of $500 \mu \mathrm{l}$ in the case of RPMI 1640 medium and F10, while for the MEM medium $1000 \mu \mathrm{l}$ was used. Good results were obtained with all the volumes tested.

Phytohemagglutinin: The volumes of phytohemagglutinin (Gibco) tested were: 10, 20, 30, 50 and $100 \mu \mathrm{l}$. It was observed that large volumes of this reagent agglutinated the cells, therefore the greatest number of metaphases was obtained with the addition of $10 \mu \mathrm{l}$ of same (Figure 2: Photo (A)). When working with 20 $\mu \mathrm{l}$ and $30 \mu \mathrm{l}$ of phytohemagglutinin, metaphases were also achieved, but these decreased in number as the concentration of this reagent increased (Figure 2: Photos (B) and (C)). To more than $50 \mu$ l of phytohemagglutinin, agglutinated nuclei were observed. 


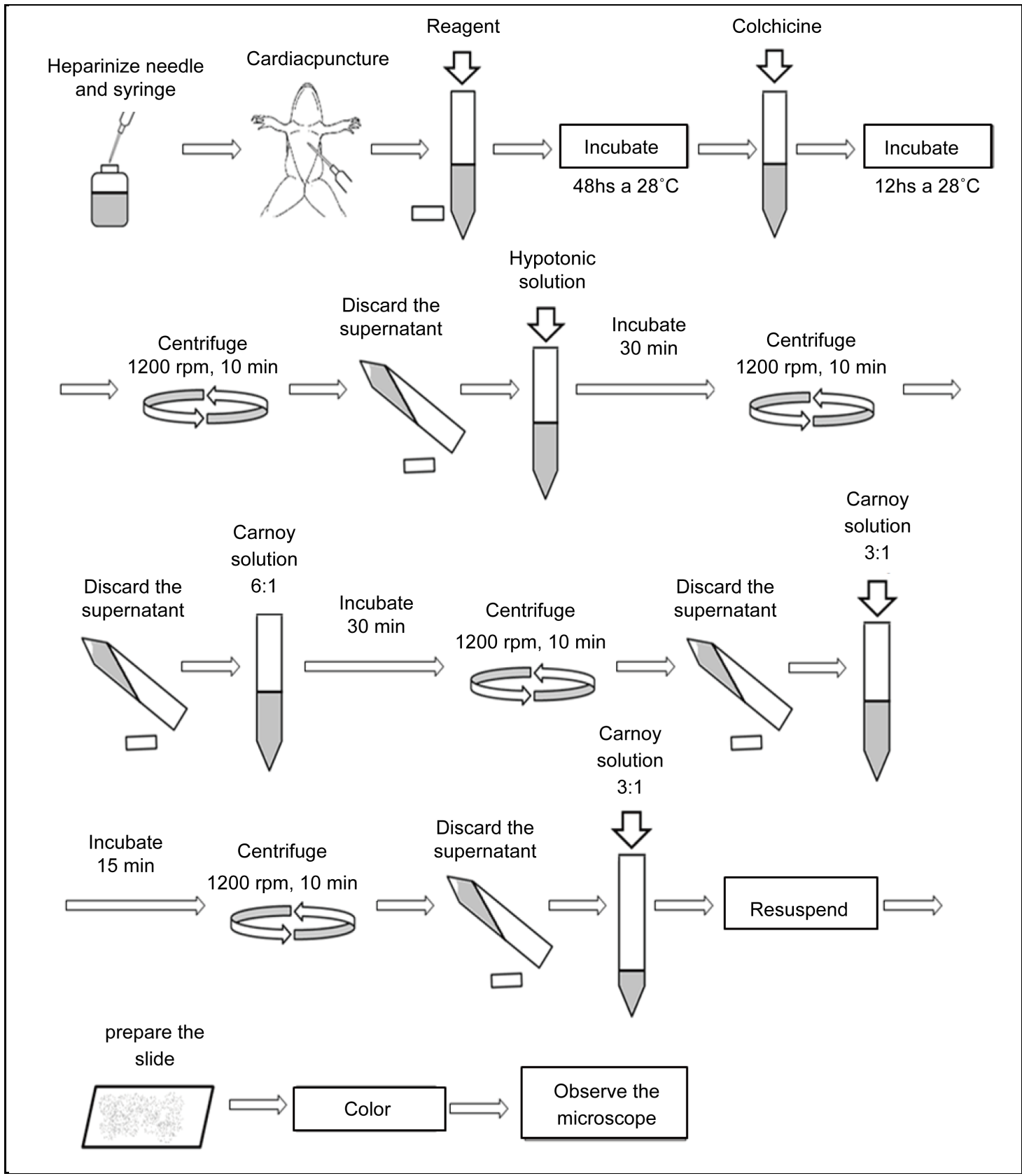

Figure 1. Protocol used for lymphocyte culture of Rhinella arenarum.
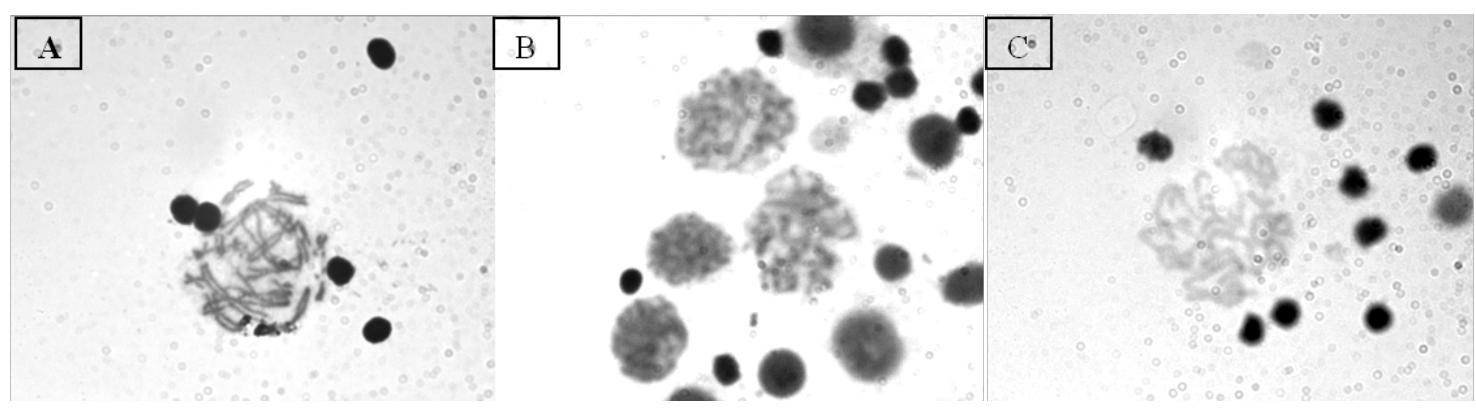

Figure 2. Metaphases. (A) With $10 \mu \mathrm{l}$ of phytohemagglutinin; (B) With $20 \mu \mathrm{l}$ of phytohemagglutinin; (C) $30 \mu \mathrm{l}$ of phytohemagglutinin. 
Streptopenicillin: It was decided to add a volume of $100 \mu \mathrm{l}$ of Streptopenicillin to the culture medium, which prevented bacterial contamination obtaining good cell growth.

Temperature and incubation time: The choice of the temperature of the stove was made based on the temperature of the amphibians of $28^{\circ} \mathrm{C}$. It was cultured for 60 hours, within which the incubation time with colchicine (12 hours) is contemplated.

Colchicine: The following volumes were tested: 100 and $200 \mu$ l. Better chromosomal size was observed with $100 \mu \mathrm{l}$ and an incubation time of $12 \mathrm{hs}$.

The definitive protocol is shown in Table 2 .

\section{Discussion}

The standardized protocol in this work is a simple and inexpensive technique, which does not require equipment or facilities of high complexity, since with a minimum equipment: microscope, culture stove, laminar flow and centrifuge can be performed the cytogenetic study, in our case, of Rhinella arenarum and that can be implemented to other species of amphibians. Regarding the obtaining of sample from peripheral blood, there are no works published in Rhinella. In all the previous works the direct method is used, even in a work done in Argentina, where they studied a population of Bufonidae. In this work they compared the karyotypes of four Rhinella species, where each specimen was injected intraperitoneally with a solution of cochicine and then sacrificed, obtaining the chromosomes of intestinal and testicular cells [20]. Comparing the direct method with the technique of lymphocyte culture, we can mention that the application of the latter, not involving the sacrifice of the specimens, has the advantage of obtaining blood samples directly thus preserving the life of wild specimens. In addition, the implementation of cell cultures in amphibians is a very useful tool for carrying out cytogenetic studies, since they allow obtaining a large number of cells and, consequently, a very high metaphase index.

Table 2. Lymphocyte culture protocol of Rhinella arenarum.

\begin{tabular}{cc}
\hline Reagent & Volume \\
\hline Sample (peripheral blood) & $100 \mu \mathrm{l}$ \\
RPMI (HEPES and glutamine) & $5 \mathrm{ml}$ \\
Fetal Bovine Serum & $500 \mu \mathrm{l}$ \\
Phytohemagglutinin & $10 \mu \mathrm{l}$ \\
Streptopenicillin & $100 \mu \mathrm{l}$ \\
Colchicine & $100 \mu \mathrm{l}$ \\
& \\
& Hypotonic solution at $0.56 \%$ \\
& Total incubation time of $60 \mathrm{hs}$ \\
& Incubation temperature $28^{\circ} \mathrm{C}$ \\
\hline
\end{tabular}


In the results obtained in this work we observed that this technique provides a good number of metaphases of good quality, an indispensable requisite for improving data on routine differential staining techniques, such as $\mathrm{G}$ banding, $\mathrm{C}$ banding or impregnation with Ag-NOR, due to the greater number of metaphases obtained when compared with direct methods.

\section{Conclusion}

The peripheral blood lymphocyte culture technique of Rhinella arenarum applied in this work is feasible and provides a large number of metaphases. In addition, it should be noted that the specimens used in this study, after the cardiac puncture, were monitored for a week and then released. This way he assures us that the specimens continued with life. With this technique chromosomal characterization can be obtained both with species that are in danger of extinction or threatened and with those out of risk.

\section{Acknowledgements}

To the members of the areas of Molecular Biology and Zoology of the National University of San Luis for providing the physical space of the laboratory of work. To the director of PROICO 2-3514, Dr. Susana Tripole.

\section{Conflict of Interest}

No potential conflict of interest was disclosed.

\section{References}

[1] Hillis, D.M. (1991) The Phylogeny of Amphibians: Current Knowledge and the Role of Cytogenetics. In: Green, D.M. and Sessions, S.K., Eds., Amphibian Cytogenetics and Evolution, Academic Press, San Diego, 7-31.

https://doi.org/10.1016/B978-0-12-297880-7.50006-8

[2] Aguiar Jr., O., Carvalho, K.A., Giaretta, A.A. and Recco-Pimentel, S.M. (2004) Cytogenetics of Hylodes and Crossodactylus Species (Anura, Leptodactylidae) with Comments on Hylodinae/Dendrobatidae Relationships. Genetica, 121, 43-53. https://doi.org/10.1023/B:GENE.0000019926.50310.26

[3] Morescalchi, A. (1990) Cytogenetics and the Problem of Lissamphibian Relationships. In: Olmo, E., Ed., Cytogenetics of Amphibians and Reptiles, Birkhäuser Verlag, Berlin, 1-19.

[4] Rodriguez Piazze, M.E. (1995) Cariotipo y patrones de bandas C en Bufo spinulosus arequipensis (Amphibia, Anura). Revista de Ecología Latino Americana, 2, 5-11.

[5] Silva, T.L., Silva, M.I.A., Venancio, L.P.R., Zago, C.E.S., Moscheta, V.A.G., Lima, A.V.B., Vizotto, L.D., Santos, J.R., Bonini-Domingos, C.R. and Azeredo-Oliveira, M.T.V. (2011) Simple Method for Culture of Peripheral Blood Lymphocytes of Testudinidae. Genetics and Molecular Research, 10, 3020-3025. https://doi.org/10.4238/2011.December.6.2

[6] King, M. and Rofe, R. (1976) Karyotypic Variation in the Australian Gecko Phyllodactylus marmoratus (Gray) (Gekkonidae: Reptilia). Chromosoma, 54, 75-87. https://doi.org/10.1007/BF00331835 
[7] Schmid, M. (1978) Chromosome Banding in Amphibia. I. Constitutive Heterochromatin and Nucleolus Organizer Regions in Bufo and Hyla. Chromosoma, 66, 361-368. https://doi.org/10.1007/BF00328536

[8] Schmid, M. (1978) Chromosome Banding in Amphibia. II. Constitutive Heterochromatin and Nucleolus Organizar Regions in Ramdae, Microhylidae and Rhacophoridae. Chromosoma, 68, 131-148. https://doi.org/10.1007/BF00287145

[9] Schmid, M., Olert, J. and Klett, C. (1979) Chromosome Banding in Amphibia. III. Sex Chromosome in Triturus. Chromosoma, 71, 29-55. https://doi.org/10.1007/BF00426365

[10] Moorhead, P., Nowell, P., Mellman, W., Battips, D. and Hungerford, D. (1960) Chromosome Preparations of Leukocytes Cultures from Human Peripheral Blood. Experimental Cell Research, 20, 613-616. https://doi.org/10.1016/0014-4827(60)90138-5

[11] Garnero, A.V., Boccelli, M., Oliveira, J.C.P., Ledesma, M.A., Montalti, D., Coria, N. and Gunski, R.J. (2013) Chromosomal Characterization of Four Antarctic Procellariiformes. Marine Ornithology, 41, 63-68.

[12] Wójcik, E. and Smalec, E. (2007) Description of the Mallard Duck (Anasplatyrhynchos) Karyotype. Folia Biologica (Kraków), 55, 3-4. https://doi.org/10.3409/173491607781492588

[13] Musa, H.H., Li, B.C., Chen, G.H., Lanyasunya, T.P., Xu, Q. and Bao, W.B. (2005) Karyotype and Banding Patterns of Chicken Breeds. International Journal of Poultry Science, 4, 741-744. https://doi.org/10.3923/ijps.2005.741.744

[14] Ramos, M.G., Descailleaux, J.L., Velásquez, M.R., Huanca, W.L., Iannuzz, L. and Perucatti, A. (2014) Adaptation of the Alpacas and Flame Lymphocyte Culture Technique for the Exchange Analysis of Sister Chromatids. Revista de Investigaciones Veterinarias del Perú, 25, 461-467.

[15] Camacho-Garzon, J. and Burbano, C. (1999) Technique for the In Vitro Culture of Fish Lymphocytes. Dahlia-Revista de la asociacion colombiana de ictiólogos, 3, 69-79.

[16] Cei, J.M. (1980) Amphibians of Argentina. Amphibians of Argentina. Monitore zoologico italiano. Monografia, 2, 173-178.

[17] Vaira, M., Akmentins, M., Attademo, M., Baldo, D., Barrasso, D., Barrionuevo, S., Basso, N., Blotto, B., Cairo, S., Cajade, R., Céspedez, J., Corbalán, V., Chilote, P., Duré, P., Falcione, C., Ferraro, D., Gutierrez, R., Ingaramo, M.R., Junges, C., Lajmanovich, R., Lescano, J.N., Marangoni, F., Martinazzo, L., Marti, R., Moreno, L., Natale, G.S., Pérez Iglesias, J.M., Peltzer, P., Quiroga, L., Rosset, S., Sanabria, E., Sanchez, L., Schaefer, E., Úbeda, C. and Zaracho, V. (2012) Categorization of the State of Conservation of the Amphibians of the Argentine Republic. Cuadernos de Herpetología, 26, 131-159.

[18] Heyer, W.R., Donnelly, M.A., McDiarmid, R.W., Hayek, L.C. and Foster, M.S. (1994) Measuring and Monitoring Biological Diversity: Standard Methods for Amphibians. Editorial Peter Strupp/Princeton Smithsonian Institution, Washington DC.

[19] Cei, J.M. (1980) Amphibians of Argentina. Monitore zoologico italiano. Monografia, 2, $609 \mathrm{p}$.

[20] Baraquet, M., Valetti, J.A., Salas, N.E. and Martino, A.L. (2011) Redescription of the Karyotype of Five Species of the Family Bufonidae (Amphibia: Anura) from Central Area of Argentina. Biologia, 66, 543-547.

https://doi.org/10.2478/s11756-011-0048-8 